\title{
FIRM-LEVEL FACTORS SEBAGAI DETERMINAN KEPUTUSAN GO PRIVATE: STUDI EMPIRIS PADA PERUSAHAAN YANG TERDAFTAR DI BURSA EFEK INDONESIA
}

\author{
Muniya Alteza \\ Naning Margasari \\ Musaroh \\ Universitas Negeri Yogyakarta \\ e-mail: muniya_alteza@yahoo.com
}

\begin{abstract}
This stud aims to examine the firm-level factors as deremininants of the going private dectsion of companies listed on the Indonesta Sroch Exchange. The study conducted based on market visibility hypothesis. The muber of sumples tised were 50 companies $(25$ companies that go private and 25 public companies). Data analysis was performed with backward stepwise of logistic regression method. The results showed that the regression analysis was free from multicollmearity problens, and test the feosibility of the model shows the goodness of fit of the logistic regression model. The results of hypothesis testing pointed out that the Debt to Asset Ratio proxy for leverage) positively affect the going private decisions. While Total Assets (proxy for size), Renum on Assets (proxy for profitability) and Market to Book Ratio (proxy forinvestment opportunity) negatively affect the going private decision.
\end{abstract}

Kenwords: fum-level factors, going private, market visibiling hoorhesis

\begin{abstract}
PENDAHULUAN
Perusahaan yang sudah tercatat di Bursa Efek ada kalanya memutuskan untuk secara sukarela keluar dari bursa. Tindakan ini disebut dengan go privaie. Keputusan go private mengakibatkan perubahan status perusahaan dari perusahaan terbuka menjadi perusahaan tertutup. Keputusan sebuah perusahaan untuk go private terkait dengan strategi pengembangan bisnis dan merupakan kepentingan bisnis masing-masing perusahaan. Hal yang periu diperhatikan bahwa keputusan go private tidak boleh merugikan pihak pemegang saham selaku pemilik perusahaan. Oleh karena itulah dalam proses go private
\end{abstract}

Bapepam-LK menekankan perlunya perlindungan kepentingan pemegang saham publik, untuk memastikan bahwa tidak terdapat infonnasi yang disembunyikan pertsahaan.

Proses go private wajib memperhatikan tercapainya keseimbangan antara hak dan kewajiban emiten maupun investor. Pada saat emiten mencatatkan sahamnya di Bursa Efek ada beberapa hal yang dicari, antara lain: pembiayaan, reputasi, dan keuntungan. Setelah kebutuhan tersebut tercapai, emiten merasa tidak perlu lagi mencatatkati sahamnya dan ingin keluar dari bursa. Kepurusan ini bagi investor bisa merugikan karena emiten memiliki prospek bagus dan mereka masih ingin mendapatkan keuntungan dari saham perusahaan bersangkutan. investor dan emiten 
sulit mencapai persetujuan harga saham karena memiliki kepentingan yang berbeda. Bapepam mempersyaratkan adanya persetujuan pemegang saham independen dan dilakukannya penawaran tender atas saham yang dimiliki pemegang saham publik. Perlindungan yang didapat melalui ketentuan penawaran tender tersebut mencakup penentuan harga saham dan kesempatant yang sama bagi semua pemegang saham publik tntuk menjual saham yang dimilikinya.

Beberapa alasan yang melatarbelakang: mengapa perusahaan melakukan aksi go private diantaranya adalah karena perusahaan sudah tidak memburthkan dana dari pasar modal dan memperoleh dana dari sumber lain, tidak mampu tumbuh lagi, mengikuti kebijakan dari perusahan induk arau karena saham perusahaan yang bersangkutan tidak lagi dapat menarik minat investor. Alasan go privare yang terakhir ini dirumuskan dalam market visibility hypothesis (Mehran dan Peristiani, 2008). Berdasarkan teori ini maka saham perusahaan yang go publik seharusnya dapat menarik minat investor untuk memiliki dan memperdagangkannya di bursa. Apabila kondisi tersebut tidak terpenuhi maka dikatakan bahwa saham tersebut market visibility-nya rendah dan hal ini menjadi salab satu pendorong utama penusahaan melakukan go private.

Kecenderungan perusahaan untuk melakukan go private dapat dipengaruhi oleh keberadaan faktor-faktor dan karakteristik spesifik yang terdapat pada tingkat perusahaan. yang disebut dengan firm-level factors (Wald. 1999). Firm-level factors ini dapat menunjukkan market visibility dari saham suatu perusahaan dan secara umum dilihat dari beberapa faktor, misalnya: bidang usaha, pasar. sumber daya, dan sebagainya. Damodaran (2001:605-606) mengungkapkan bahwa faktor-faktor unik dari sebuah perusahaan memiliki peranan penting dalam pengambilan keputusan strategik seperti misalnya perubahan status menjadi perusahaan publik dan sebaliknya. Beberapa peneliti telah melakukan penelitian mengenai vartabel-variabel yang memengaruhi kepurusan suatu perusahaan untuk melakukan go protate. Ponelitian yang dilakukar: Weir et al. (2004) menyimpulkan bahwa perusahaan yang melakukan tindakan go private mayoritas mempunyai ukuran perusahaan lebih kecil. jenis tisaha yang ltbih bervariasi dan mempunyai nilai pasar yang dithat dari Tobin's $Q$ yang lebila rendah dibandingkan perusahaan yang mempertahankan starus sebagai pensahaan publik. Selain itu penelitian lainnya dilakukan oleh Witmer (2005) yang menyimpulkan perusahaan yang memiliki persentase perputaran saham di bursa yang rendah lebih cenderung akan melakukan voluntary delisting. Sedangkan penelitian yang dilakukat Mehran dat Peristiani (2008) menemukan bahwa perusahaan dengan peluang pertumbuhan rendah yang dicerminkan dari nilai market to book ratio yang kecil dan mempunyai perputaran saham (stock fumover ratio) yang rencah akan dipandang sebagai perusahaan yang tidak menarik oleh investor sehingga conderung melakukan tindakan go private. Di Indonesia sendiri penelitian go private jumlahnya masih terbatas, antara lain dilakukan oleh Nurhidayati dan Harahap (2002) yang menemukan ternyata ada empat rasio keuangan yang secara statistik berbeda signifikan antara perusahaan yang bertahan listing dengan perusahaan yang mengalami delisting yaitu Earning Per Share (EPS). Equity Per Share (EqPS). Debr Equity Ratio (DER). Net Profit Margin (NPM), dan Retum On Equity (ROE). Berdasarkan latarbelakang di atas maka penelitian ini bertujuan untuk mengetahui pengaruh variabe! firm-level factors terhadap keputusan perusahaan dalam melakukan go private. 


\section{REVIEW LITERATUR DAN HIPOTESIS}

\section{Go Private (Voluntary Delisting)}

Menurut Darmadji dan Fakhrudin (2001: 70) delisting adalah penghapusan efek dari daftar efek yang tercatat di bursa. Penghapusan pencatatan saham perusahaan tercatat dari daftar efek yang terjadi di bursa dapat terjadi karena: 1) Permohonan penghapusan pencatatan saham yang diajukan oleh perusahaan tercatat yang bersangkutan atau disebut voluntary delisting: dan 2) Dihapus pencatatan sahamnya oleh bursa sesuai dengan peraturan bursa, Jika perusahaan terkena delisting, maka efek dari perusahaan yang bersangkutan tidak dapat lagi diperjualbelikan di bursa. Beberapa alasan perusahaan delisting anatara lain periggabungan perusahaan, penutupan perusahaan, dan gagalnya perusahaan memenuhi persyaratar pasar modal setempat untuk tetap Iisting (Koetin, 2002), Delisting dilakukan karena bermacam-macam alasan, misalnya: karena transaksi dalam efek tersebut sangat jarang terjadi meskipun perusahaan yang bersangkutan kinerjanya tetap baik. Kemungkinan juga jumlah pemegang sahamnya sangat kecil apalagi jika pemegang efek yang bersangkutan kebanyakan investor yang lebih suka menyimpan efek untuk waktu yang lama sehingga efek yang bersangkutan menjadi tidak likuid.

Voluntary delisting (go private) adalah perubahan status perusahaan dari perusahaan terbuka menjadi perusahaan tertutup, artinya perusahaan yang sahamnya semula dimiliki oleh publik (perusahaan terbuka), berubah kembali menjadi perusahaan tertutup yang dimiliki oleh sedikit pemegang saham saja. Istilah go private dapat pula berarti pemerintah menjual, sebagian atau semua, saham miliknya kepada investor swasta atau masyarakat. Pengertian go private terutama dimaksudkan sebagai keputusan voluntary delisting (bukan karena dipaksa oleh otoritas bursa) yang dilakukan oleh perusahaan terbuka.

\section{Market Visibility Hypothesis dan Firm-Level Factors}

Market visibility hypothesis merumuskan bahwa saham perusahaan yang telah terdaftar di Bursa Efek seharusnya harus dapat menarik minat investor untuk memiliki dan memperjualbelikannya. Jika saham dipandang tidak menarik lagi sehingga daya jualnya rendah maka dikatakan saham tersebut market visibility-nya rendah. Hal ini menjadi salah satu pendorong perusahaan melakukan go private.

Market visibility dari suau perusahaan dapat dilihat antara lain dari variabel level perusahaan yang disebut dengan firm-level factors. Menurut Wald (1999) fim-level factors adalah variabel-variabel yang menunjukkan karakteristik spesifik yang melekat pada suatu perusahaan. Karakteristik suatu perusahaan bisa dilihat dari beberapa faktor, antara lain: bidang usaha, pasar, sumber daya dan sebagainya. Dalam konteks laporan ketuangan penentuan karakteristik perusahaan bisa ditetapkan dengan menggunakan tiga pendekatan kategori yang dilakukan oleh Lang dan Lundholm (1993) yaitu: karakteristik yang berhubungan dengan structure, perfornance dan market. Variabel struktur mencerminkan kondisi fundamental perusahaan. Macam variabel yang masuk dalam kategori ini antara lain adalah ukuran perusahaan, leverage, dan volatilitas pendapatan. Sedangkan variabel kinerja umumnya berupa rasio profitabilitas, yaitu rasio yang mengukur kemampuan suatu perusahaan dalam menghasilkan laba. Beberapa rasio profitabilitas yang sering digunakan adalah retumon assets, retum on equity, net profif margin. earning per share dan lain sebagainya. Variabel pasar mencerminkan sejauh mana fundamental perusahaan dihargai oleh pasar. Pada umumnya variabel ini digunakan untuk mengukur minat atau preferensi investor terhadap saham bersangkutan, yang dilihat dari indikator di bursa saham. Salah satu cara untuk menentukan minat investor adalah dengan mengukur relative 
stock trading tumover: Apabila investor tertarik untuk berinvestasi pada suaru saham tertentu maka saham tersebut biasanya akan sering ditransaksikan selingga memiliki iumover ratio yang tinggi. Saham yang dipilih investor tentunya juga tidak sembarangan melainkan saham yang berpotensi memberikan retum yang optimal yang implisit juga berarti emiten penerbit saham memiliki fundamental yang bagus. Oleh karena itu perputaran saham (stoch turnover) adalah indikator yang berguna dalam menilai intensitas informasi dan minat investor.

Penelitian empiris mengenai voluntary delisfing masih relatif jarang dijumpai dalam literatur manajemen keuangan di Indonesia. Penelitian delisting antara lain dilakukan oleh Nurhidayati dan Harahap (2002) Penelitian tersebut menggunakan sampel 36 perusahaan yang delisting dan 45 perusahaan yang listing dari periode 1995 sampai 2002. Hasil pengujiannya menemukan bahwa dari sembilan rasio keuangan yang dijadikan sebagai alat prediksi bagi perusahaan yang mengalami delisting di BEJ, ternyata ada empat rasio keuangan yang secara statistik berbeda signifikan antara perusahaan yang bertahan listing dengan perusahaan yang mengalami delisting yaitu Eaming Per Share (EPS), Equity Per Share (EqPS), Debr Equiry Ratio (DER), Net Profit Margin (NPM), dan Return On Equity (ROE).

Penelitian yang dilakukan Weir et al. (2004) menggunakan sampel perusahaan yang melakukan go privare dari tahun 1990 sampai 2002 di Inggris. Penelitian ini menyimpulkan bahwa dibandingkan dengan perusahaan yang tetap mempertahankan status publik maka perusahaan yang melakukan tindakan go private conderung mempunyai ukuran perusahaan lebih kecil, tingkat diversifikasi lebih tinggi dan memiliki rasio Tobin's Q yang lebih kecil. Pengujian yang dilakukan oleh Macey. O'Hara dan Pompilio (2004) mengaitkan kemungkinan perusahaan go private dengat biaya kebangkrutan yang mungkin harus ditanggung perusahaan. Menurut mereka, perusahaan dengan volarilitas pendapatan yang tinggi akan memiliki probubilitas mengalami kesulitan keuangan yang lebil tinggi pula. khususnya pada perusahaan yang menggunakan tingkat utang cukup besar. Porusahaan semacam ini menanggung risiko gagal bayar relatif tinggi sehingga sahamnya kurang diminati investor. Hal inilah yang lalu mendorong perusahaan mengambil keputusan go pititate.

Sclain itu penclitian yang lainnya dilakukan oleh Witmer (2005) menggunakan sampel perusahaan delising di NYSE. AMEX, dan NASDAQ dari tahuri 1990 sampai 2003. Penelitian ini menyimputikan perusahaan dengan persentase perputaran sahamnya rendah lebih cenderung akan melakukan voltwany delisting. Stock tumoser ratio adalah rasio volume perdagangan saham dengan malket capicalization. Penelitian ini juga membandingkan dari beberapa negara. dan hasilnye menyebuttar. perusahaan lobih cenderung akan molakukm voluntary delisting jika mereka dari negara dengan perlindungan hukum yang lemali terhadap investomya. Hasil inj sesuai dengan pengujian yang dilakukan olch Jackowicz dan Kowalewski (2007) yang menyimpulkan bahwa probabilitas go private pada perusahaan meningkat dengan konsentrasi kepemilikan asing yang tinggi. kenaikan besaran free cash flow; dan penurunan likuiditas perdagangan saham.

Boot. Gopalan dar Thakor (2007) dalam pengujiannya menemukan bahwa keputusan perusahaan publik berubah menjadi perusahaan privat dipengaruhi oleh partisipasi investor, yang tercemin dalam level dan volatilitas harga saham. Studi empiris Jainnya dilakukan oleh Mehran dan Peristiani (2008) menggumakan sampel perusahaan yang go public dan menjadi go private dari tahun 1990 sampai 2004 dan mengambil kelompok kontrol perusahan vang tetap go public pada NYSE. Penelitian ini menggunakan variabel analtust growth, change instimutional 
ownership, stock turnover ratio, stock volatility: debt ratio, market ro book ratio dan stock retum. Hasilnya menyebutkan bahwa perusahaan dengan pertumbuhan kecil yang diukur melalui market to book ratio dan mempunyai perputaran saham yang rendah (stock tumover ratio) lebih cenderung akan melakukan tindakan go private.

\section{Hipotesis}

Pada dasarnya salah satualasanpensahaan mengubah statusnya menjadi perusahaan publik adalah tujuan memperoleh dana segar dari investor. Guna mencapai tujuan ini maka saham perusahaan bersangkutan haruslah dapat menarik minat pasar (investor) untuk memiliki dan memperdagangkan saham. Dalam hal ini dikatakanbahwa sahamterseburharuslahmemiliki market visibility yang cukup tinggi (Mehran dan Peristiani, 2008). Akan tetapi ada kalanya saham yang sudah go publik temyata tidak memiliki market wisibilin yang tinggi, artinya gagal menarik minat investor untuk mentransaksikan saham tersebut, sehingga akhimya perusahaan memutuskan untuk melakukan voluntary delisting (go private). Go private ini merupakan tindakan dimana perusahaan secara sukarela memutuskan untuk tidak mencatatkan maupun memperdagangkan lagi sahamnya di bursa. Kecenderungan perusahaan unruk melakukan go private antara lain dapat dilihat dari firmlevel factor's yaitu faktor-faktor dan karakteristik spesifik yang terdapat pada tingkat perusahaan. Firm-level factors ini dapat menunjukkan matket visibility dari saham suatu perusahaan, sehingga akhimya dapat menentukan apakah tetap terdaftar atau keluar dari bursa. Dalam penelitian ini digunakan variabel fim-level factors yang terdiri dari variabel struktur meliputi leverage, ukuran perusahaan dan volatilitas pendapatan, variabel kinerja yang mencakup profitabilitas, dan variabel pasar yang terdiri dari likuiditas saham dan kesempatan investasi. Secara keseluruhan semakin baik kondisi perusahaan yang diukur melalui beberapa indikator tersebut (struktur, kinerja dan pasar) kemungkinan perusahaan untuk melakukan go vrivate semakin kecil.

Rasio leverage diproksikan oleh debt to toral assets ratio dan debt to eguty ratio. Semakin besar debt to total assets ratio dan debt to equity ratio maka semakin tidak pasti kelangsungan hidup perusahaan karena kekayaan atau modal sendiri yang dimiliki belum tentu mencukupi untuk membayar seluruh kewajibannya. Perusahaan dengan rasio leverage yang terlalu tinggi juga mengindikasikan probabilitas munculnya kesulitankeuanganyangtinggisehinggasahamnya relatif kurang dapat menarik minat investor. Oleh karena sahamnya tidak diminati oleh investor maka perusahaan publik memutuskan untuk tidak memperdagangkan lagi sahamnya di bursa (go private). Hipotesis yang diajukan adalah:

Hla: Debt to Assets Ratio berpengaruh positif terhadap keputusan go private

$\mathrm{Hlb}$ : Debt to Eqtiry Ratio berpengaruh positif terhadap kepurusan go private

Ukuran perusahaan dapat diproksikan oleh total asset dan total sales. Semakin besar ukuran suatu perusahaan maka perusahaan lebih mudah dalam memasuki pasar modal, semakin besar modal yang ditanamkannya pada berbagai jenis usaha, sehingga memperoleh penilaian kredit yang tinggi dari pasar. Dengan demikian kecenderungan perusahaan besar untuk mempertahankan statusnya sebagai perusahaan publik lebih besar dibandingkan perusahaan kecil. Hipotesis yang diajukan adalah:

H2a: Total .4ssets berpengaruh negatif terhadap keputusan go private.

$\mathrm{H} 2 \mathrm{~b} \quad$ : Fotal Sales berpengaruh negatif terhadap keputusan go privare.

Variabel lainnya adalah volatilitas pendapatan, yang dapat dilihat dari standar deviasi basic earning power. Perusahaan dengan volatilitas pendapatan yang tinggi akan memiliki risiko yang lebih tinggi pula dan cenderung tidak menarik minat investor untuk memiliki sahamnya 
sehingga kemungkinan untuk keluar sukarela dari bursa saham semakin besar pula. Dengan demikian dapat dirumuskan hipotesis sebagai berikut:

H3 : volatilitas pendapatan berpengaruh positif terhadap keputusan go private.

Profitabilitas menunjukkan kemampuan sebuah perusahaan untuk menghasilkan laba. Dua rasio keuangan yang sering digunakan sobagai indikator profitabilitas, yaitu retwin on assets (ROA) dan remun on cquity (ROE). Semakin baik profitabilitas perusaluan maka perusahaan diharapkan memiliki prospek yang bagus di masa depan dan dipandang semakin menarik oleh investor. Hal ini mettorong saham perusahaan tersebut semakin diminati sehingga cenderung untuk bertahan sebagai pertusahaan publik. Sesuai dengan teori ini maka hipotesis yang diajukan adalah

$\mathrm{H} 4 \mathrm{a}$ : Retum on Assets berpengaruh negatif terhadap keputusan go private.

$\mathrm{H} 4 \mathrm{~b}$ : Retunt on Equity berpengaruh negatif terhadap keputusan go private.

Tingkat likuiditas saham yang dilihat dari perputaran saham istock twmover) adalah indikator yang berguna dalam menilai intensitas informasi dan mintat investor terhadap saham tersebut. Semakin tinggi tingkat perputaran saham menunjukkan investor lebih tertarik untuk memperjualbelikan saham tersebut lewat transaksi yang dilakukannya. Hal ini berani bahwa saham tersebut dapat memiliki market visibility yang tinggi dan perusahaan akan lebih suka bertahan sebagai pertsalhaan publik karena sahamnya diminati investor. Hipotesis yang disusun adalah:

H5 : Likuiditas saham berpengaruh negatif terhadap keptususan go private.

Kesempatan investasi yang tinggi mencerminkan kondisi perusahaan yang masih bertumbuh. Apabila kesempatan investasi yang tersedia cukup banyak dan feasible, tercemin dari nilai market to hook ratio yang semakin besar maka pemsahaan dipandang semakin menarik oleh investor sehingga sahamnya relatif dicari. Oleh karena itu kemungkinan perusahaan bersangkutan untuk go privare akan semakin kecil. Berdasarkan hal ini disusun hipotesis sebagai berikut:

H6 : Kesempatan investasi berpengaruh negatif terhadap keputusan go private.

\section{METODE PENELITIAN}

\section{Populasi dan Sampel}

Populasidalampenelitianiniadalahsahamsaham perusahaan yang melakukan corporate action yaitu tindakan go private dan perusahaan yang tetap memperahankan status go public di Bursa Efek Indonesia. Teknik pengambilan sampel yang dipakai dalam penelitian ini adalah purposive sampling. yaitu teknik penentuan sampel dengan kriteria tertentu. Adapun kriteria yang digunakan untukmenenukan sampel adalah: 1) Perusahaan yang pertiah terduftar di Bursa Efek Indonesia menjadi perusahaan go public: 2) Perusahaan go public yang melakukan go private pada periode 2000-2007 dan telah disetujui oleh Bapepam; dan 3) Memiliki kelengkapan data yang dibutuhkan dalam penelitian. Sedangkan sampel untuk comparison firm yaitu perusahaan yang mempertahankan status go publik diambil secara purposive dengan kriteria sebagai berikut: 1) Perusahaan yang tetap go public dan masih mempertahankan status perusahaan tersebut pada periode penelitian: 2) Berasal dari jenis industri yang sama dengan perusahaan go private; dan 3) Memiliki kelengkapan data yang dibutuhkan dalam penelitian.

\section{Definisi Operasional Variabel}

Variabel terikat dalam penelitian ini adalah keputusan perusahaan untuk melakukan go privare (volmaty delisting) yang bersifat kategorikal sehingga variabel ini berupa dumm: Nilainya 1 untuk perusahaan yang melakukan 
tindakan go private dan 0 untuk perusahaan yang tetap go public. Sedangkan variabel independen dalam penelitian ini adalah:

1) Leverage, diproksikan dengan debt to total assets ratio (DAR) dan debt to equity ratio $(D E R)$.

$$
\text { DAR }=\frac{\text { Total Hutang }}{\text { Total Assets }}
$$

$$
\text { DER }=\frac{\text { Total Hutang }}{\text { Total Modal Sendiri }}
$$

2) Ukuran perusahaan, diproksikan dengan Total Asset (TA) dan Total Sales (TS) sebagai ukuran perusahaan.

3) Volatilitas pendapatan. dihitung dari standar deviasi basic earning power selama tiga tahun sebelum perusahaan go private. Dinumuskan:

$$
\text { VOLAT }=\sigma\left(\frac{E B I T}{\text { Total Assets }}\right)
$$

4) Profitabilitas diproksikan dengan Retum On Assets (ROA) dan Return On Equit (ROE).

$$
\begin{aligned}
& \text { ROA }=\frac{\text { Laba Bersih }}{\text { Total Aktiva }} \\
& \text { ROE }=\frac{\text { Laba Bersih }}{\text { Modal Sendiri }}
\end{aligned}
$$

5) Likuiditas saham diproksikan Stock Tumover Ratio (STR). Variabel ini diukur dari sebagai berikut:

$$
\mathrm{STR}=\frac{\text { StockTradingVolume }}{\text { Market Capitalization }}
$$

6) Kesempatan investasi diproksikan market to book rario (MBR). Variabel ini dihitung sebagai berikut:

$$
\mathrm{MBR}=\frac{\text { Market I alue of Equity }}{\text { Book Thlue of Equity }}
$$

\section{Model Penelitian}

Lntuk melihat pongaruh firm-level factors terhadap keputusan go privare digunakan regresi logistik, yaitu model regresi di mana variabel dependennya adalah probabilitas mendapatkan dua hasil berdasarkan fungsi non linear dari kombinasi linear sejumlah yariabel independen (Kuncoro, 2001). Adnpun persamaan regresinya adalah:

$Y=\beta_{0}-\beta_{1}(D A R)-\beta_{2}(D E R)+\beta_{3}\left(\operatorname{Ln}{ }_{-} T A\right.$ )$-\beta_{-}\left(\mathrm{Ln}_{-}\right.$IS $)+\beta_{5}($ VOLAT $)+\beta_{f}(\mathrm{ROA})+$ $\beta_{.}($ROE $)-\beta_{8}($ STR $)-\beta_{9}($ MBR $)+\varepsilon$

Y : Variabel dummy dari keputusan go private atau tetap go public.

DAR : Debr to total assets ratio

DER : Debit to equitu ratio

In TA : Logarima natural total aset

Ln_TS : Logartima natural total penjualan

VOLAT: volatilitas pendapatan

$$
\begin{array}{ll}
\text { ROA } & \text { : Retum on assets } \\
\text { ROE } & \text { : Return on equity } \\
\text { STR } & \text { : stock mumover ratio } \\
\text { MBR } & \text { : market to book ratio } \\
\varepsilon & \text { : emor }
\end{array}
$$

Uji signifkansi terhadap koefisien regresi logistik dilakukan menggunakan Wald statistic (Hair et al., 1998) yang ditunjukkan oleh nilai p-value. Cara menafsir regresi logistik dengan pendekatan probabilitas. Di sini tidak ada probabilitas negatif atau lebih dari satu sehingga:

- Koefisien negatif dianggap probabilitas 0 yang berarti perusahaan cenderung tidak melakukan go private 
- Koefisien positif lebih dari 1, dianggap probabilitas 1 yang berarti pensahaan cenderung melakukan go privaie.

- Koefisien positif antara 0 sampai I maka probabilitas perusahaan melakukan go private sesuai dengan besarnya nilai koefisien.

\section{HASIL PENELITIAN DAY PEMBAHASAN}

Jumlahperusahaan di BursaEfekIndonesia yang melakukan go private pada periode 20002007 adalah 47 perusahaan. Sampel diambil menggunakan puposive sampling dan diperoleh 25 perusahaan yang memenuhi kriteria. Selain itu dalam penelitian ini juga dibutuhkan perusahaan pembanding (comparison firm), dalam hal ini perusahaan yang tetap mempertahankan go public pada periode penelitian dan memenuhi kriteria penelitian sejumlah 25 perusahaan. Staristik deskriptif dari data penelitian disajikan dalam tabel berikut:

Tabel 1

Statistik Deskriptif Data

\begin{tabular}{|c|c|c|c|c|c|}
\hline \multicolumn{6}{|c|}{ S-mpel Go Prowate } \\
\hline & S & $\begin{array}{l}\text { Sini- } \\
\text { murm }\end{array}$ & $\begin{array}{l}\text { Barki- } \\
\text { muts }\end{array}$ & $34+4=0$ & Statfat Devast \\
\hline $\begin{array}{l}\text { Debor fo Asi- } \\
\text { ser Raria }\end{array}$ & 23 & 0.015022 & 5.142713 & 0,91920431 & 1.932362233 \\
\hline $\begin{array}{l}\text { Dutht no Ey- } \\
\text { uin Ranip }\end{array}$ & $\underline{x}$ & $0,0055=0$ & $65,4+1812$ & $4,56353 \div-66$ & $1.100+86 \%+25 t$ \\
\hline $\begin{array}{l}\text { Lat Toral } \\
\text { Asseri }\end{array}$ & 25 & $501+i 2=1$ & $7.45 m=$ & $5003 \cdots+2$ & $6572+016185$ \\
\hline $\begin{array}{l}\text { Int'Toral } \\
\text { Sales) }\end{array}$ & 25 & 3.071265 & 6.255045 & $5.63062: 5$ & 0,075782382 \\
\hline $\begin{array}{l}\text { Yolatiftas } \\
\text { Pendapatat1 }\end{array}$ & 25 & 0.915300 & $0.40=-15$ & $0.140 \div 356$ & $0,1: 60605 \%$ \\
\hline $\begin{array}{l}\text { Rerion on } \\
\text { diser }\end{array}$ & 25 & $0,00204 \%$ & $1,714 \div 4$ & $0,133908-3$ & $0,20025:=0=$ \\
\hline $\begin{array}{l}\text { Retiom ont } \\
\text { Equits }\end{array}$ & 25 & 0.00405 & $13,14 \div 06$ & 0.2967627 & $2 \sin 66: 3 \times 9$ \\
\hline $\begin{array}{l}\text { Shock Tum- } \\
\text { over Ruato }\end{array}$ & 25 & Qิง & 0,71954 & $0.6932715^{-}$ & 0.191580222 \\
\hline $\begin{array}{l}\text { Market fo } \\
\text { Book Ratio }\end{array}$ & 25 & 0.000 का & 4.340000 & inculeson & $\{.213210221$ \\
\hline \multicolumn{6}{|c|}{ 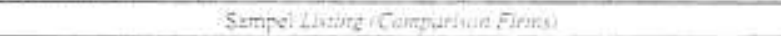 } \\
\hline & $\mathrm{N}$ & $\begin{array}{l}\text { Mini- } \\
\text { Tintin- }\end{array}$ & $\begin{array}{l}\text { Maks:- } \\
\text { Thint }\end{array}$ & Lfeat: & Standar Deriasi \\
\hline $\begin{array}{l}\text { Dethl th ist } \\
\text { set Ratio }\end{array}$ & 25 & $600+162$ & $156665 \%$ & $0.65,5-2.40$ & $0 .+6 \div 23+10 !$ \\
\hline 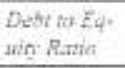 & 25 & $0.07 \div \div 3$ & $2: 01 \leq 549$ & 2.15373200 & S20.982:573 \\
\hline
\end{tabular}

\begin{tabular}{|c|c|c|c|c|c|}
\hline $\begin{array}{l}\text { Artiotial } \\
\text { Atoxt }\end{array}$ & $\pm z$ & $4,593 \times 40$ & 6,5001031 & 6,02178259 & 0,466956794 \\
\hline $\begin{array}{l}\text { Intraral } \\
\text { Stivi }\end{array}$ & 25 & $4+40053$ & $6,350,590$ & $5,6165+307$ & $0.4^{*} 5811964$ \\
\hline $\begin{array}{l}\text { Giatilitas } \\
\text { Pencapaten }\end{array}$ & 28 & $0,083+18$ & 0,$62685 ; 0$ & Q, $1031316 !$ & 0,1252220711 \\
\hline $\begin{array}{l}\text { Rertuns yint } \\
\text { Axsed }\end{array}$ & 25 & $0,001 \times 0=$ & 0,971349 & 0.1249054 & $0.210657 \times 57$ \\
\hline $\begin{array}{l}\text { Retum ar } \\
\text { Foniti }\end{array}$ & 25 & $0.005 \leq 366$ & 2,950310 & $0,38: 46870$ & $0.653921 \times 4$ \\
\hline $\begin{array}{l}\text { Srock Thre- } \\
\text { mor Ratio }\end{array}$ & 25 & 0,000000 & $14+9019$ & 0,14399914 & $0,35 \$ \$ 10 \$ 56$ \\
\hline $\begin{array}{l}\text { Herkest in } \\
\text { Alouk Zartip }\end{array}$ & 25 & 0.060000 & 10,500000 & $1.5-400000$ & 2,364705668 \\
\hline
\end{tabular}

Sumber hastl olah data

Berdasarkan tabel di atas dapat diketahui bahwa nilai rata-rata leverage (Debr 10 Asset dan Debt to Equity Ratio) serta volatilitas pendapatan kelompok perusahaan go private lebih tinggi daripada rata-rata kelompok perusahaan yang mempertahankan status listing. Data ini menjadi indikasi awal bahwa semakin tinggi nilai kedua variabel tersebut maka kecenderungan go private akan semakin besar. Sedangkan dari data ukuran perusahaan yang diproksikan dengan toral sales dan toral asset maupun kesempatan investasi lewat proksi Market to Book Rotio tertihat bahwa nilai rata-rata dari kelompok sampel perusahaan go private lebih kecil dibandingkan rata-rata kelompok perusahaan listing. Hal ini mengindikasikan bila perusahaan yang memiliki ukuran dan kesempatan investasi lebih besar cenderung mempertahankan starusnya sebagai perusahaan publik. Rata-rata stock timnover kelompok sampel listing lebih tinggi dibandingkan kelompok sampel go privare sehingga ini menjadi pendukung bahwasanya semakin tinggi stock tumover yang bemakna semakin tinggi pula likuiditas saham maka kecenderungan perusahaan melakukan go private semakin kecil.

\section{Uji Asumsi Klasik}

Regresi logistik adalah regresi dengan asumsi yang berbeda dengan regresi linier OLS yaitu: 1) Enor tem variabel dependen berupa variabel diskrit yang mengikuti distribusi tidak normal sehingga semua pengujian statistik berdasar asumsi normalitas tidak lagi valid; 
2) Dalam regresi ini varian emor tem adalah heteroskedastik karena tergantung pada harapan bersyarat dari $Y$ yang tentu saja tergantung pada nilai yang diambil $X$. Akhimya varian error term tergantung pada $X$ dan tidak homoskedastik. Hal ini tetap terjadi pada kondisi tidak ada autokorelasi. Oleh karena itulah maka dalam regresi logistik ini hanya diperlukan uji asumsi klasik berupa uji multikolineartas.

Tabel 2

Hasil Uji Multikolinearitas

\begin{tabular}{|c|c|c|c|c|}
\hline \multirow{2}{*}{ No } & \multirow{2}{*}{ Variabel } & \multicolumn{2}{|c|}{$\begin{array}{l}\text { Collwearity } \\
\text { Stutisucic }\end{array}$} & \multirow{2}{*}{ Kesimpulan } \\
\hline & & Toler- & VIF & \\
\hline 1. & $\begin{array}{l}\text { Debt to As- } \\
\text { set Ratio }\end{array}$ & 0,609 & 1.643 & Non Multikolinaaritas \\
\hline 2. & $\begin{array}{l}\text { Debr io Eq- } \\
\text { wir: Ratio }\end{array}$ & 0,665 & 1.504 & Non Multikolinearitas \\
\hline 3. & $\begin{array}{l}\text { In (Total As- } \\
\text { sets) }\end{array}$ & 0.570 & 1.754 & Non Multikolinearitas \\
\hline 4. & $\begin{array}{l}\text { Lit (Total } \\
\text { Sales) }\end{array}$ & 0.609 & 1.643 & Non Multikolincaritas \\
\hline 5. & $\begin{array}{l}\text { Volatilitas } \\
\text { Pendapatan }\end{array}$ & 0.511 & 1.637 & Non Mutrikolinearitas \\
\hline o. & $\begin{array}{l}\text { Renum an } \\
\text { Assel }\end{array}$ & 0.884 & 1.131 & Non Multikolinearitas \\
\hline 7. & $\begin{array}{l}\text { Renum on } \\
\text { Equity }\end{array}$ & 0,715 & 1.399 & Non Multikolinearitas \\
\hline 8. & $\begin{array}{l}\text { Stack Tumo- } \\
\text { ver Rato }\end{array}$ & 0.750 & 1.333 & Non Multikolinearitas \\
\hline 9. & $\begin{array}{l}\text { Wartel to } \\
\text { BookRatio }\end{array}$ & 0,738 & 1.356 & Non Multikolinearitas \\
\hline
\end{tabular}

Sumber: hasil olah data

Pengujian multikolinearitas dilihat melalui angka VIF dan Tolerance. Dari sembilan variabel terlihat bahwa tidak ada satu pun variabel yang memiliki VIF di atas 10 dan Tolerance kurang dari 0,10 . Oleh karena itu dapat dismpulkan bahwa tidak ada multikolinearitas antar variabel bebas dalam model regresi logistik.

\section{Uji Kelayakan Model Regresi}

Sebelum dilakukan pengujian hipotesis maka dalam penelitian int dilakukan pengujian prasyarat analisis benpa uji kelayakan model regresi. Regresi logistik (binany logistic regression yang dipakai menggunakan metode backward stepnise (conditional). Penggunaan metode ini dimaksudkan untuk menyaring satu per satu variabel mdopenden sampai mendapatkan model yang paing haik menurut metode ini. Berdasarkan metode ini terjadi empat kali tahap regresi dan model vant terbaik menurut hachtrard stepwise adalah model yang terakhir Rangkuman hasil pengujian kelayakan model regresi logistik model terbaik menurut bachward stepwise terlihat dalam tabel berikut:

\section{Tahel 3}

Hasil Lji Kelayakan Model Regresi Logistik

\begin{tabular}{|c|c|c|c|c|}
\hline \multicolumn{5}{|c|}{ Tabel Klasifflkasi } \\
\hline \multirow[b]{3}{*}{ Observasi } & \multicolumn{4}{|c|}{ Prediksi } \\
\hline & \multicolumn{2}{|c|}{ Keptusan } & \multirow{2}{*}{\multicolumn{2}{|c|}{ Persentase Benar }} \\
\hline & $\begin{array}{l}\text { Trank } \\
\text { stosk } \\
\text { salit }\end{array}$ & $\begin{array}{l}\text { Stoch } \\
\text { splif }\end{array}$ & & \\
\hline Oefridak stoek & 21 & 4 & & 84 \\
\hline $\begin{array}{l}\text { splii) } \\
\text { I (Stockispilit) } \\
\text { Onsorall } \\
\text { Percentage }\end{array}$ & 3 & 22 & & \\
\hline \multicolumn{5}{|c|}{ 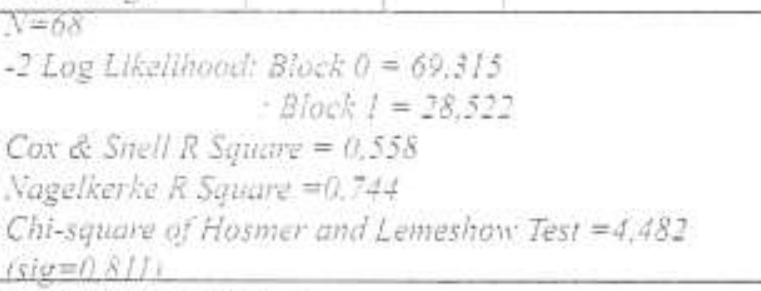 } \\
\hline
\end{tabular}

Sumber: hasil olah data

Tabel 3 menunjukkan berbagai indikator untuk menilai kelayakan model regresi. Nilai orerall percentage unruk tabel klasifikasi cukup tinggi yairu sebesar $86 \%$, artinya sampel mayoritas dapat diklasifikasi dengan benar oleh model regresi. Indikator lain adalah nilai -2 Log Likelihood yang mengaiami penurunan dari 69.315 (Block 0) meniadi 28,522 (Block 1). Penurunan nilai ini menunjukkan model yang lebih baik. Adapun variasi variabel dependen yang bisa dijelaskan dengan baik oleh model adalah $55.80 \%$ berdasar Cox \& Snell $R$ Square dan $74,40 \%$ berdasarkan Vagelherke $R$ Square, 
Angka ini menunjukkan bahwa model regresi logistik cukup baik dalam memprediksi keputusan perusahaan melakukan go privare karena explanatory power-nya lebih dari $50 \%$. Untuk indikator terakhir adalah Chi-square of Hosmer and Lemeshow Test sebesar 4,482 dengan p-value 0,647 dan tidak signifikan pada taraf signifikansi $5 \%$. Berarti model regresi layak untuk analisis karena tidak ada perbedaan yang nvata antara klasifikasi yang diprediksi dengan klasifikasi yang diamati. Berdasarkan indikator goodness of fit maka disimpulkan bahwa model regresi ini layak untuk memprediksi keputusan perusahaan (go private atau tetap listing).

\section{Uji Hipotesis}

Metode bachicard stepwise, ini pada awalnya akan menguji semua variabel penelitian kemudian mengeluarkan satu per saru variabel yang tidak signifikan dari model, sehingga model yang terakhir muncul adalah model yang terbaik untuk digunakan. Dalam model pertama dimasukkan sembilan variabel independen dan diperoleh hasil variabel volatilitas pendapatan memiliki nilai yang paling tidak signifikan. Oleh karena itu variabel ini dikeluarkan dari regresi berikutnya sehingga regresi tahap kedua hanya memasukkan delapan variabel saja. Hal ini menunjukkan bahwa volatilitas pendapatan bukan merupakan prediktor yang baik bagi keputusan go private, sehingga $\mathrm{H} 3$ ditolak. Temuan ini bertentangan dengan bukti empiris pengujian Macey, O'Hara dan Pompilio (2004) bahwa tingginya volatilitas pendapatan mengakibatkan perusahaan menghadapi risiko yang lebih tinggi pula, terlebih pada perusahaan yang menggunakan utang. Dalam regresi model ketiga dikeluarkan lagi satu variabel yaitu Debi to Equity Ratio (DER) sebagai proksi leverage. Hal ini berarti bahwa $D E R$ bukan merupakan prediktor yang baik dalam model penelitian ini. Oleh karena itu maka $\mathrm{HIb}$ yang menyatakan bahwa DER berpenganh positif terhadap kepurusan go private ditolak. Hasil ini tidak sesuai dengan penelitian Nurhidayati dan Harahap (2002) yang menyatakan bahwa DER adalah rasio yang membedakan perusahaan yang bertahan listing dan perusahaan yang mengalami delisting.

Model yang terakhir diperoleh dari pengujian regresi logistik adalah model keempat, dimana yariabel proksi ukuran yaitu total sales dikeluarkan dari model. Hal ini menunjukkan bahwa total sales bukan merupakan prediktor yang baik bagi keputusan go private dan $\mathrm{H} 2 \mathrm{~b}$ ditolak, Hasil ini bertentangan dengan bukti dari pengujian Witmer (2005) dan Mehran dan Peristiani (2008) bahwa semakin besar foral sales maka probabilitas perusahaan go private semakin kecil. Variabel yang tersisa untuk diuji kembali sebanyak enam variabel. Model keempat ini adalah model yang terbaik menurut regresi logistik dengan metode backward stepwise. Hasil pengujian model kcempat terangkum dalam tabel berikut

Tabel 4

Hasil Pengujian Hipotesis (Model Terakhir Menurut Backward Stepwise)

\begin{tabular}{|c|c|c|c|c|c|}
\hline Viriabe: & Fonks! & $\begin{array}{l}\text { Seefivien } \\
\text { Eta }\end{array}$ & Waid & $\begin{array}{l}\text { Signia. } \\
\text { kanihi }\end{array}$ & Aeterangun \\
\hline Bonerame & & Ift: & - खरा & $11=$ & stountor \\
\hline Leterdeg & 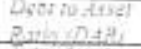 & 1.759 & 3.895 & $0,04:=$ & Signitikus \\
\hline 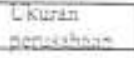 & 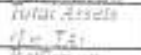 & $-2,239$ & 4.294 & $0,0,0$ & Signigkat \\
\hline \multirow[b]{2}{*}{ Frottabilitas } & 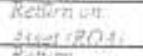 & -7.956 & $5.8 \leq 4$ & 0,016 & Signitikaft \\
\hline & $\begin{array}{l}\text { Rething } \\
\text { an Equis } \\
\text { geE }\end{array}$ & 5,959 & 2.330 & 0.127 & $\begin{array}{c}\text { Tidak } \\
\text { Srgnitikin }\end{array}$ \\
\hline $\begin{array}{l}\text { Likudtas } \\
\text { saham }\end{array}$ & 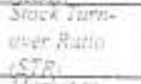 & -6.075 & $-7,-94$ & 0.029 & Signifikan \\
\hline $\begin{array}{l}\text { Kescinpelat } \\
\text { iftestast }\end{array}$ & $\begin{array}{l}\text { Murket bi } \\
\text { Bonk Rotio } \\
\text { wesi }\end{array}$ & $.0,540$ & 4.525 & 8.023 & Signitkan \\
\hline
\end{tabular}

Sumber: hasil olah data

Koefisien variabel leverage yang diproksikan oleh Debt to Asset Ratio sebesar 1,759 yang signifikan pada level $5 \%$ sehingga Hla diterima. Semakin tinggi Debt to. 4 ssets Ratio betarti semakin tinggi rasio utang perusahaan dibandingkan dengan assetsnya dan semakin besar probabilitas perusahaan mengalami 
kesulitan membayar hutangnya kembali sehingga memperbesar kemungkinan kebangkrutan. Saham semacam ini memiliki market visibility rendah artinya tidak dapat menarik minat investor untuk memiliki dan memperdagangkan saham tersebut. Hal ini mendorong semakin besamya probabilitas perusahaan mengambil keputusan go private. Temuan empiris ini sesuai dengan penelitian Weir et al. (2004). Jackowicz dan Kowalewski (2007) dan Mehran serta Peristiani (2008) yang menemukan bahwa rasio utang terhadap assets berpengaruh positif terhadap keputusan go private yang diambil suatu perusahaan.

Kocfisien ukuran perusahaan dengan proksi Total Assets sebesar -2.239 yang signifikan pada level $5 \%$ sehingga $\mathrm{H} 2$ a diterima. Ukuran perusahaan berpengaruh positif terhadap keputusan go private dimana semakin besarukuran maka semakin besar probabilitas perusahaan melakukan go private. Ukuran yang semakin besar memberikan kemudahan bagi perusahaan untuk mengakses pasar modal guna memperoleh tambahan dana schinggasemakin besarpula modal yang dapat ditanamkan pada berbagai jenis usaha. Selain itu perusahaan besar jenis usahanya relatif lebih terdiversifikasi sehingga mengurangi risiko. Faktor ini mengakibatkan saham perusahaan besar akan menarik minat investor (market visibility tinggi) sehingga cenderung mempertahankan status listing di bursa dibandingkan dengan perusahaan kecil. Hasil ini mendukung penelitian Weir et al. (2004) yang menemukan bahwa ukuran perusahaan berpenganh positif terhadap keputusan go private.

Variabel selanjutnya adalah proksi profitabilitas yaitu ROA memiliki koefisien $-7,756$ yang signifikan pada level $5 \%$ sehingga $\mathrm{H} 4 \mathrm{a}$ diterima. ROA berpengaruh negatif terhadap keputusan go pritate artinya semakin besar ROA maka probabilitas perusahaan melakukan go private semakin kecil. Hasil ini sesuai dengan penelitian Jackowicz dan Kowalewski (2007). Mehran dan Peristiani (2008). Perusahaan dengan ROA tinggi berarti kemampuannya menghasilkan laba dengan asset yang dimiliki cukup tinggi sehingga dapat menarik minat investor. Tingginya minat investor terhadap saham ini akan mondorong perusahasn untuk mempertahankan statusnya sebagai perusahaan publik. Proksi profitabilitas lainnya yaitu ROE memiliki koefisien 1,969 yang tidak signifikan pada level $5 \%$ sehingga H4b ditolak. Hasil yang tidak signifikan ini dapat dijelaskan melalui statistik deskriprif, di mana nilai standar deviasi ROE yang lebih besar dibandingkan nilai ratarata, baik untuk kelompok sampe! perusahaan go private maupun tetap listing. Ini berarti bahwa terdapat banyak variasi data atau kesenjangan data antara nilai maksimum dan minimum terlalu besar. Bukti empiris ini tidak sesuai dengan hasil penelitian Nurhidayati dan Harahap (2002) yang menemukan perbedaan ROE yang signifikan antara perusahaan listing dan delisting. Selain itu temuan ini juga tidak mendukung bukt! empiris Witmer (2005) yang juga memproksikan profitabilitas dengan ROE berpengaruh negatif signifikan terhadap kepurusan go privare.

Proksi likuiditas saham yairu Stock Tumover Ratio memiliki koefisien $-6,025$ dan signifikan pada level $5 \%$ sehingga $\mathrm{H} 5$ diterima. Likuiditas saham berpengaruh negatif terhadap keputusan go private. Semakin tinggi stock tumover ratio maka saham semakin likuid sehingga tentunya mempunyai market visibility yang tinggi, karena imestor lebih menyukai memegang saham yang aktif diperdagangkan. Sahan yang market wisibility-nya tinggi memiliki kemungkinan go pritgte semakin kecil. Hasil ini konsisten dengan penelitian Mehran dan Peristiani (2008).

Sedangkan variabel terakhir yaitu Market to Book Ratio sebagai proksi dari kesempatan investasi memiliki koefisien $-0,590$ yang signifikan pada level $5 \%$ sehingga H6 diterima. MBR berpengaruh negatif terhadap keputusan go private artinya semakin besar MBR yang 
bermakna semakin banyak kesempatan investasi yang tersedia maka probabilitas perusahaan mengambil keputusan go private semakin kecil pula. Hasil ini mendukung penelitian Witmer (2005), Jackowicz dan Kowalewski (2007), Mehran dan Peristiani (2008). Menurut market visibility hypothesis, perusahaan yang memiliki kesempatan investasi tinggi akan lebih mudah menarik investor untuk memiliki saham tersebut karena peluang mendapat return dari kesempatan investasi yang memiliki net present value positif. Situasi ini pada akhimya akan mendorong perusahaan untuk mempertahankan statusnya sebagai perusahaan yang terdaftar di bursa.

\section{KESIMPULAN DAN SARAN}

Penelitian ini bertujuan untuk menganalisis pengaruh firm-level factors sebagai determinan keputusan go private. Hasil pengujian berhasil membuktikan bahwa leverage, ukuran perusahaan, volatilitas pendapatan, profitabilitas dan kesempatan investasi berpengaruh terhadap keputusan go privare. Penelitian ini membawa implikasi bahwa sebaiknya investor dalam berinvestasi saham memperhatikan faktor market visibility dariperusahaanyang dilihat daribeberapa rasio keuangan di antaranya Debt to Assets Ratio, Retum on Assets. Stock Tumover Ratio dan Market to Book Ratio. Semua rasio tersebut dapat dilihat untuk melihat kecenderungan saham perusahaan bersangkutan untuk tetap terdaftar di bursa atau ticlak.

Beberapa keterbatasan dari penelitian ini diantaranya adalah penelitian hanya memasukkan indikator keputusan go private yang bersumber dari rasio keuangan dan jumlah sampel yang relatif terbatas, yaitu hanya 25 perusahaan yang melakukan go private dan 25 perusahaan yang mempertahankan status sebagai perusahaan go publik, Oleh karena itu bagi penelitian selanjutnya dapat memperpanjang periode penelitian sehingga dapat diperoleh sampel yang lebih banyak. Selain itu penelitian juga dapat memastkkan indikator lain dalam keputusan go privatesepertiperusahaan cenderung untuk go private bila berasal dari negara dengan perlindungan investor lemah (bonding hyporhesis) atau memiliki kepenilikan institusional tinggi (monitoring hypothesis).

\section{DAFTAR PUSTAKA}

Boot, Arnoud WV. A, Radhakrishman Gopalan and Anjan V. Thakor. 2007. "Market Liquidity, Investor Participation and Managerial Autonomy: Why do Firms Go Private?". Social Science Research Network Journal, w7nt:sstn.com?

Damodaran, Aswath. 2001. Corporate Finance: Theory and Practice. Second Edition. New York: John Wiley and Sons, Inc

Damadji dan Fakhruddin. 2001. Pasar Modal Indonesia Pendekatan Tanya Jawab. Jakarta: Salemba Empat

Hair et al. 1998. Multivariate Analisis. Fifth Edition. Singapore: Prentice Hall International, Ine

Jackowicz Krzysztof and Oskar Kowalewski 2007 "Why Companies Go Private in Emerging Markets? Evidence from Poland". Social Science Research Nerwork Joumal, umissrncom

Macey, Jonathan, O'Hara Maureen. Pompilio. David. 2004. "Down and Out in the Stock Market: The Law and Finance of the Delisting Process". Social Science Research Network Journal, mmissm. com

Koetin, E.A. (2002). Analisis Pasar Modal. Jakarta: Pustaka Sinar Harapan

Kuncoro, Mudrajat. 2001. Metode Kuantitatif Teori dan Aplikasi untuk Bisnis dan Ekonomi. Edisi pertama. Yogyakarta: AMP YKPN 
Lang. M., and R. Landholm. (1993) "Cross Sectional Determinant of Analyst Ratings of Corporate Disclosure". Journal of Accounting Research. p 246-271

Mehran, Hanid and Stavros Peristiani. (2006). "Financial Visibility and the Decision to Go Private". Social Science Research Network Joumal, www.ssm, com

Nurhidayati dan Sofyan Harahap. 2002. "Rasio Keuangan Sebagai Alat Prediktor Delisting Perusahaan". Jumal Media Riser Bisnis dan Manajemen, 10, 1-34

Wald, John K. 1999. "How Firn Characteristics Affect Capital Structure: An Intemational Comparison". Joumal of Financial Researich. Vol.XXII. No,2, p161-187
Weir, Charlie et al. 2004. "Financial Distress Costs. Incentive Realigmment, Private Equity and the Decision to Go Private: Public to Private Actixity in the UK". Social Science Research Networt Joumal, wusw:Ssmicom

Witmer, L, Jonathan. 2005. "Why do Firms Cross-(de)list? An Examination of the Determinants and Effects of Crossdelisting". Social Science Research Nenwork Joumal, nww.ssm.com 